\title{
Tectonic Evolution of the Active "Chelif" Basin (Northern Algeria) from Paleomagnetic and Magnetic Fabric Investigations
}

\author{
Derder M.E.M. ${ }^{1}$, Henry B. ${ }^{2}$, Amenna M. ${ }^{1}$, Bayou B. ${ }^{1}$, Maouche S. ${ }^{1}$, Besse J. ${ }^{2}$, \\ Abtout A. ${ }^{1}$, Boukerbout H. ${ }^{1}$, Bessedik M. ${ }^{3}$, Bourouis S. ${ }^{1}$ and Ayache M. ${ }^{1}$ \\ ${ }^{1}$ C.R.A.A.G., BP 63, 16340 Bouzaréah, Alger, \\ 2Paléomagnétisme, IPGP, PRES Sorbonne Paris Cité and CNRS, \\ ${ }^{3}$ Laboratoire de Paléontologie Stratigraphie et Paléoenvironnement, \\ Université d'Oran \& Université Hassiba Benbouali Chlef, \\ ${ }^{1,3}$ Algeria \\ ${ }^{2}$ France
}

\section{Introduction}

The present-day crustal deformation in the North African area is mainly driven by the NWSE to NNW-SSE convergence (4-5 mm/yr) between the African and Eurasian plates (Mckenzie, 1972; Nocquet \& Calais, 2004; Serpelloni et al., 2007). This convergence is accommodated over a wide deformation zone (the Tellian Atlas) implying the existence of significant seismic activity. This domain represents the southern part of the Alpine ranges at the boundary between the African and Eurasian plates. It is characterized by E-W to NE-SW trending folds and thrust belt and composed by an "external zone" with Mesozoic to Tertiary rocks and an "internal zone" consisting of a thrust stack of metamorphic complexes and Mesozoic calcareous and flysch. Overlying these previous series, Neogene to Quaternary sediments fill the intramountainous basins, limited by E-W and NE-SW faults as evidenced in the "Chelif" basin (Chiarabba et al, 1996; Meghraoui, 1982; Meghraoui, 1988; Thomas, 1985). Few studies were dedicated to these faults (Aoudia \& Meghraoui, 1995; Chiabbara et al., 1996; Meghraoui, 1988; Phillip \& Meghraoui, 1983), consequently the timing and amount of displacement of these faults, as well as their relationship with the Neogene basin development, are still a matter of debate (Thomas, 1985; Neurdin-Trescartes, 1992; Belkebir et al., 1996; Bessedik et al., 2002). The seismic activity is mainly characterized by moderate to destructive magnitude events as it was shown by the recent 21 May 2003 Zemmouri earthquake (Mw=6.8) (Meghraoui et al., 2004) and the 10 October $1980 \mathrm{El}$ Asnam (presently Chlef) earthquake (Mw=7.3) (Ouyed et al.,1981). These two earthquakes are the strongest recent ones that occurred in this part of Western Mediterranean area. According to the Algerian earthquake catalogue (Benouar, 1994) the earthquake activity is mainly concentrated in the intramountainous seismogenic basins which belongs to the Tellian Atlas. The convergence movement between Africa and Eurasia plates involves a tectonic transpression with N-S to NNW-SSE direction, which initiate faulting activity along "en echelon" NE-SW trending folds and associated reverse faults. This "en echelon" system 
should be likely due to the presence of deep E-W strike-slip faults (Meghraoui et al., 1996 and references therein). In the Chellif Mio-Plio-Quaternary intramountainous seismogenic basin, the active tectonic witnesses are highlighted by recent Quaternary tectonic structures activated during the earthquakes: e.g. "El-Asnam" reverse fault $(2 \mathrm{~m}$ coseismic average deformation during the $1980 \mathrm{Mw} 7.3$ El-Asnam earthquake) and "Tenes Abou El Hassan" fault ( $1 \mathrm{~m}$ average coseismic deformation during the 1922 Ms 6 earthquake - Philippe \& Meghraoui, 1983; Aoudia \& Meghraoui, 1995).These active NE-SW faults are associated with asymmetric folds. These different tectonic structures define several NE-SW oriented tectonics blocks (Morel \& Meghraoui, 1996). As suggested by Meghraoui et al., (1996), the active deformation could be explained by a simple kinematic model of block rotation related to the transpression with NNW-SSE direction of plates convergence.

This new study aims to quantify the tectonic activity of the Chelif basin. This work will particularly focus on rotations in this active basin (as suggested by preliminary paleomagnetic results - Aiffa et al., 1992) in order to improve a block rotation model based on the oblique Africa-Europe convergence (Meghraoui et al., 1996). Paleomagnetic and Anisotropy of Magnetic Susceptibility (AMS) analyses were thus performed (using larger sampling area 66 sites) in the Miocene and Pliocene sedimentary rocks cropping out in this basin

\section{Geological setting}

The intramountainous Chelif basin is located in Northern Algeria within the Tellian atlas (Fig. 1). It is a "post-thrust" basin elongated in an E-W direction. It is bordered to the north by the "Dahra" and "Bou-Maad" hills, mainly constituted of allochtonous Cretaceous and Upper Oligocene allochtonous formations. To the south, it is limited by the "Ouarsenis" mountains which are formed by Lower Jurassic and Cretaceous allochtonous formations. The Chelif basin constitutes one of the Neogene "post-thrust" basins located in the northern Algeria (e.g. the "Constantine", "Soumam" and "Mitidja" basins), resulting from the distention, which affected this area during the Lower-Middle Miocene (Thomas, 1985; Neurdin-Trescartes, 1992; Belkebir et al., 1996).

From stratigraphical point of view, it is constituted by Mio-Plio-Quaternary deposits overlaying a basement formed by thrust sheets with Mesozoic series (Fig. 1) (Anderson, 1936; Perrodon, 1957; Belkebir et al., 1996). The bottom of the basin series is represented by the blue marls and gray calcareous sandstones of Uppermost Burdigalian and Langhian - Serravallian ages (Belkebir et al., 1996; Bessedik et al., 2002). Overlying the latter, the Tortonian formation is constituted by limestones, marls and sandstones. The Messinian ones are formed by blues marls alternating with diatomites, crowned by (Lithothamnium and/or coral) limestones on the platforms, and finally massive gypsum or interbedded stratifications within marls and sandstones intercalations. The Pliocene formation is mainly represented by marls, sandstone, calcareous sandstone, calcarenite, and conglomerate. Friable red sandstones and sandy to silty deposits constitute the Quaternary formation. The history of the Chelif basin began by a subsidence during the Late Burdigalian (Meghraoui, 1982; Bessedik et al., 2002) and was stopped at the end of the Langhian detritic sedimentation located in the northern part of the Ouarsenis relief which reveals the absence of the Serravallian sedimentation and testifies the end of the Ouarsenis thrust establishment. The sedimentation continued during the Lower Serravallian in the Northern part of the Chelif basin (Bessedik et al., 2002), followed by a Lower Tortonian extensional phase with 
formation of large grabens. After the deposit of the Lower Pliocene, an important NNE-SSW compressive phase deformed the Tortonian and Messinian formations (Meghraoui et al., 1986). A second important compression phase occurred during the Quaternary, with a NNW-SSE to NW-SE shortening direction. It affected the Quaternary deposits and accentuated the deformation of the older series (Meghraoui, 1982).

The neotectonic studies (Philippe \& Meghraoui, 1983, Meghraoui et al., 1986) showed that the present deformation in the Chelif basin is mainly related to a transpression with N-S to NNW-SSE shortening direction, which is expressed by active tectonic responsible of the earthquake activity. Indeed, NE-SW trending folds and NE-SW active sinistral transpressive faults were activated during the 1954 and 1980 destructive earthquakes (Bezzeghoud et al., 1995; Ouyed et al., 1981). These reverse faults and related folding are disposed on right lateral echelon and should be coupled with NW-SE to E-W trending strike-slip deep active faults.

\section{Sampling and analysis procedure}

Different formations outcropping in this basin have been extensively (879 oriented cores distributed over 66 sites) sampled (Fig. 1). The sampling was made in the gray calcareous sandstone of Lower Miocene age (65 samples from 4 sites), the Tortonian gray limestone (147 samples from 10 sites), the dark marls, the fine red limestone and gray marls of Messinian age (191 samples from 12 sites), and the Pliocene marls, sandstone, calcareous sandstone and calcarenite (478 samples from 40 sites).

One to three specimens were cut from each core in order to have additional specimens for paleomagnetic pilot studies, rock magnetic analysis and magnetic fabric measurements. Prior to any demagnetization analysis, the specimens were stored in a zero field for at least one month, in order to reduce a possible viscous magnetization component. The Natural Remanent Magnetization (NRM) of the specimens was measured using a JR5 spinner magnetometer (AGICO, Brno). Several pilot specimens from each site were subjected to a stepwise alternating field and thermal demagnetizations in order to characterize their magnetic behavior.

The results of the pilot study evidenced that significant part of the samples have very weak magnetization, showing moreover very unstable remanent magnetization behavior during the thermal demagnetization process. The corresponding sites have been then discarded.

For the other samples, the obtained results showed that the AF procedure did not allow complete demagnetization. Thermal demagnetization was then applied to the remaining specimens. It was performed using a cylindrical furnace with a fast heating level while forced air enhanced the cooling. In order to correctly isolate and identify the magnetization components, numerous steps were performed, with increments ranging from $70^{\circ} \mathrm{C}$ at the lowest temperatures to $10^{\circ} \mathrm{C}$ at the highest one, up to $670^{\circ} \mathrm{C}$ maximum temperature.

Finally, 350 samples were successfully demagnetized in this study. The demagnetization data analysis was carried out using classical methods: the direction of the magnetization components was computed using principal component analysis (Kirschvink, 1980) and plotted on orthogonal vector plots (As \& Zijderveld 1958; Zijderveld 1967); the remaining vectors and vectorial differences of the magnetization were plotted on equal-area projections. The mean direction of the different components was computed using (Fisher, 1953) statistics. Fold tests of McElhinny (1964) and reversal test of McFadden \& McElhinny (1990) were performed when applicable. 


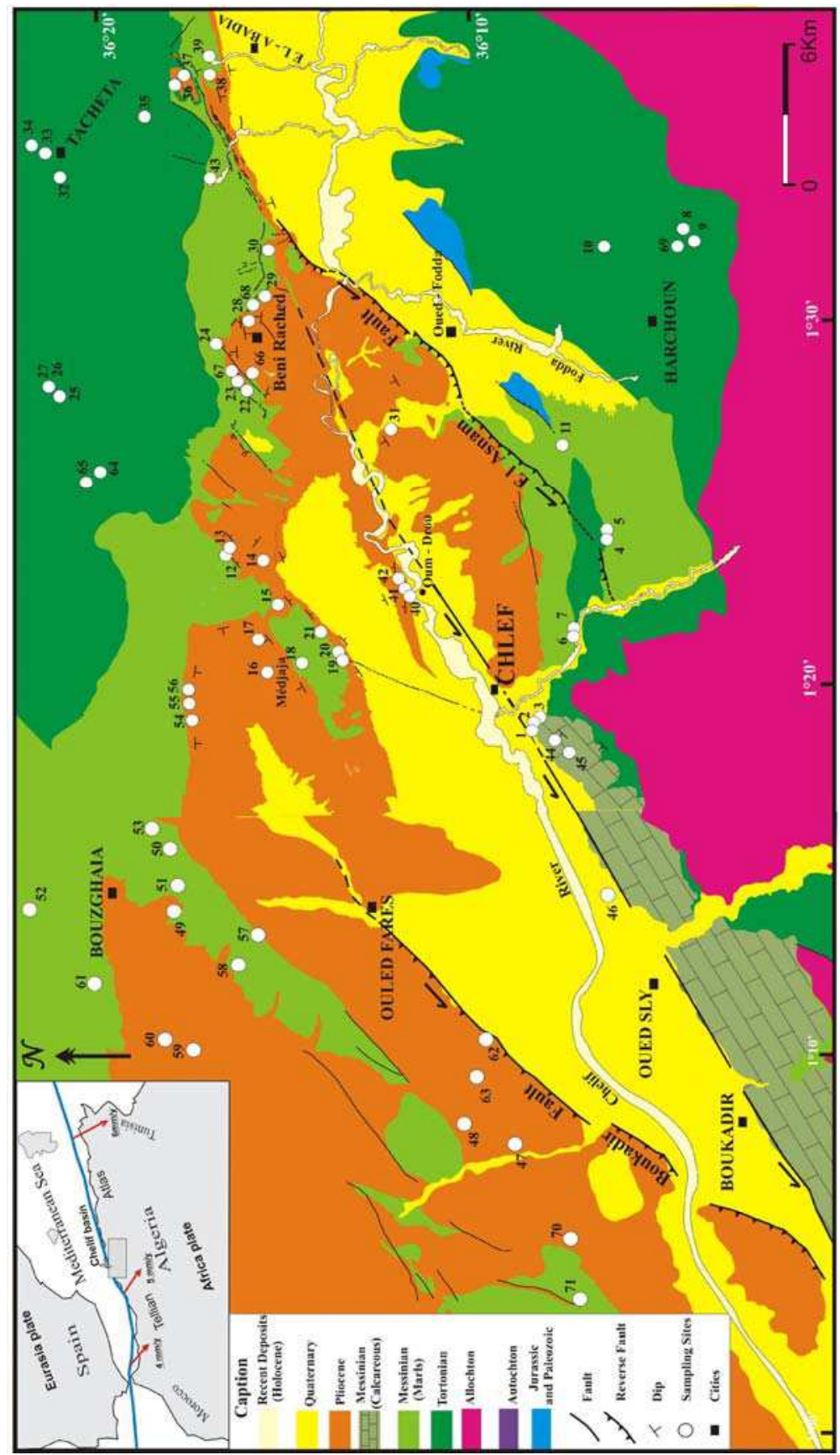

Fig. 1. Geological map of the "Chelif" basin area (after Anderson, 1936; Meghraoui et al., 1986; Meghraoui, 1988) modified, and location of the sampling sites 


\section{Rock magnetism}

The NRM intensity measured on the samples from the different geological formations is often very weak. It varies from 0.01 to $910^{-6} \mathrm{~A} / \mathrm{m}$. The maximum unblocking temperature (Tunb) spectra seems very large, from 670 to $250^{\circ} \mathrm{C}$. The maximum Tunb changes within each formation; indeed, for the Lower Miocene samples, it varies from 350 to $670^{\circ} \mathrm{C}$, (mostly between 480 and $600^{\circ} \mathrm{C}$ ). For the Tortonian formation, it is between 260 and $630^{\circ} \mathrm{C}$, mainly below $440^{\circ} \mathrm{C}$, while for the Messinian samples, the window is from 350 to $600^{\circ} \mathrm{C}$ (mostly between 430 and $510^{\circ} \mathrm{C}$ ). Ending, for the Pliocene formation, the maximum Tunb spectra is between 250 and $635^{\circ} \mathrm{C}$, but mainly with values below $480^{\circ} \mathrm{C}$. Notice that even, if some maximum Tunb values greater than $580^{\circ} \mathrm{C}$ have been obtained (evidencing the presence of hematite), the majority of the Tunb values are lower than $580^{\circ} \mathrm{C}$.

Thermomagnetic curves (low-field susceptibility as a function of temperature) were determined using CS3 equipment - Kappabridge KLY3 (AGICO, Brno, Czech Republic) on crushed representative samples. To point possible mineralogical alteration due to heating, heating and cooling curves have been compared, even during partial cooling loops during the initial heating. Few samples (all from the Messinian formation) yield reversible curves (Fig. 2 - sample 93 of Messinian age) showing the absence of chemical alteration of the ferromagnetic minerals during heating. Some others samples show weak alteration (Fig. 2sample 315 of Pliocene age) indicated by slightly different heating and cooling curves. But most samples present important mineralogical alteration (shown by a strong magnetic susceptibility irreversible increase which occurs during the heating at about $400-500^{\circ} \mathrm{C}$ (e.g. Fig. 2 - sample 469 from Tortonian formation). The main reversible variation of the susceptibility up to $580^{\circ} \mathrm{C}$ corresponds to the magnetite Curie temperature (Fig. 2; samples 93, 315 and 469). However, part of the evidenced magnetite was clearly formed during mineralogical alteration in samples with no reversible heating and cooling curves. In some samples (on Fig. 2 - e.g. 315 of Pliocene age), small variation of the magnetic susceptibility at temperatures higher than $600^{\circ} \mathrm{C}$ could correspond to the presence of hematite.
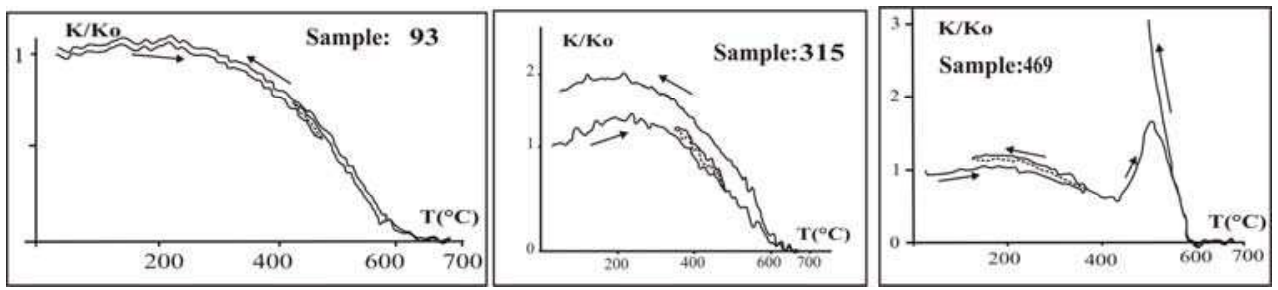

Fig. 2. Thermomagnetic curves: Normalized low field susceptibility (K/Ko) as a function of the temperature $\mathrm{T}$ (in ${ }^{\circ} \mathrm{C}$ ) for samples 93,469 and 315

Hysteresis loops were measured on small samples (about $3 \mathrm{~cm}^{3}$ ) using a translation inductometer within an electromagnet. The loops are almost linear, pointing out a largely dominant effect of the paramagnetic minerals. Because of the weak magnetization, only loops corrected for the paramagnetism yield usable indications about the magnetic mineralogy (Fig. 3). The total saturation of the magnetization is not reached despite application of magnetic field of $0.8 \mathrm{~T}$ intensity, confirming the presence of hematite (Fig. 3 samples $469,315,93$ ). A partial saturation, related to a low coercive mineral, explains that 
the coercive force varies mainly from $114 \mathrm{mT}$ (Tortonian samples) to $44 \mathrm{mT}$ for (samples from the Messinian formation); few weaker values of $27 \mathrm{mT}$ have been also obtained for the Pliocene samples.

As a conclusion, the magnetic mineralogy includes mainly magnetite (relatively low coercivity), but hematite (high coercivity) is also often present, mostly in weak amount.

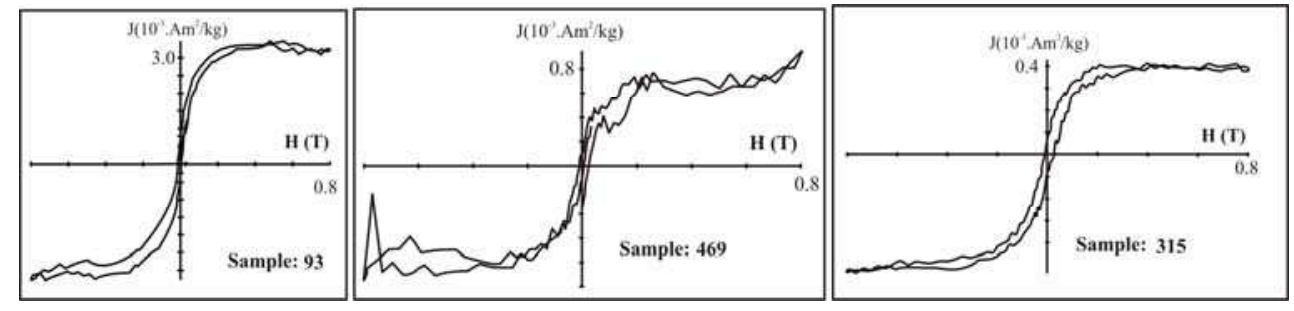

Fig. 3. Hysteresis loops after correction for paramagnetism for samples samples 93, 469 and 315 - $\mathrm{J}$ in $10^{-3} \mathrm{~A} \cdot \mathrm{m}^{2} / \mathrm{kg}$ and $\mathrm{H}$ in $\mathrm{T}$

\section{Paleomagnetic results}

The weakness of the magnetization intensity and the frequent magnetization instability observed during the thermal treatment due to mineral alteration did not allow obtaining a reliable paleomagnetic datum for part of the samples. A dramatic decrease of the magnetization intensity is observed at about $80-100^{\circ} \mathrm{C}$, during the thermal demagnetization process of most Pliocene and Messinian samples. In some other samples, mineralogical alteration, shown by a strong increase of the magnetization intensity, occurs at $200-300^{\circ} \mathrm{C}$. The corresponding Zijderveld diagrams present then an erratic behavior and no magnetic component can be isolated. However, few Pliocene and Messinian samples show, after elimination of a viscous component, a linear segment in these diagrams defining a Characteristic Remanent Magnetization (ChRM) carried by magnetite (illustrated by maximum Tunb about $500^{\circ} \mathrm{C}$ - Fig. $4 \mathrm{a}$, samples 688 and 387 of Pliocene age and Fig. 4b, samples 11 and 25 of Messinian age). Similarly, in some samples of Messinian age, after an evolution of the magnetization direction along great circles (remagnetization circles) for the lowest temperatures, a stable direction is reached at the highest temperatures defining a ChRM carried by hematite (maximum Tunb reaches $\sim 600^{\circ} \mathrm{C}-$ e.g. Fig. $4 \mathrm{c}$, sample 117). For most Tortonian samples, after an evolution along remagnetization circles at the lowest temperatures, either the magnetization intensity became too weak or mineralogical alteration occurs, and no magnetic component can be isolated. However, few Tortonian samples show, after elimination of a viscous component, a linear segment defining a ChRM carried by magnetite (maximum Tunb $\sim 500^{\circ} \mathrm{C}$ - Fig. $4 \mathrm{~d}$, sample 073). In the Lower Miocene samples, an evolution along remagnetization circles occurs at the lowest temperatures (until $\sim 250^{\circ} \mathrm{C}$ ). At highest temperatures, two cases are observed: either a mineralogical alteration occurs shown by erratic behavior on the Zijderveld diagrams, or a ChRM, carried by magnetite, can be defined (e.g. sample 154, Fig. 4e), or hematite (e.g. sample 125, Fig. 4f maximum Tunb $\sim 650^{\circ} \mathrm{C}$ ). ChRM, with normal or reversed polarity, has been isolated in the different sampled formations and are distributed in several sites (Fig. 5). Its direction varies, 
depending on the sites location and on the studied geological formations (Fig. 5a, b, c, and d).

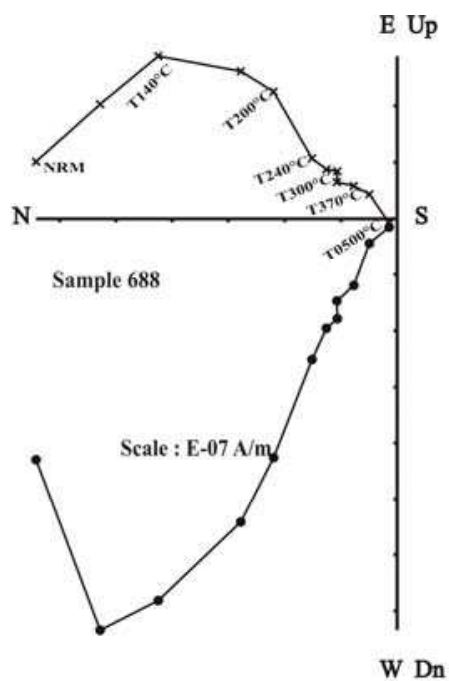

Horizontal Plane • Vertical Plane $\times$

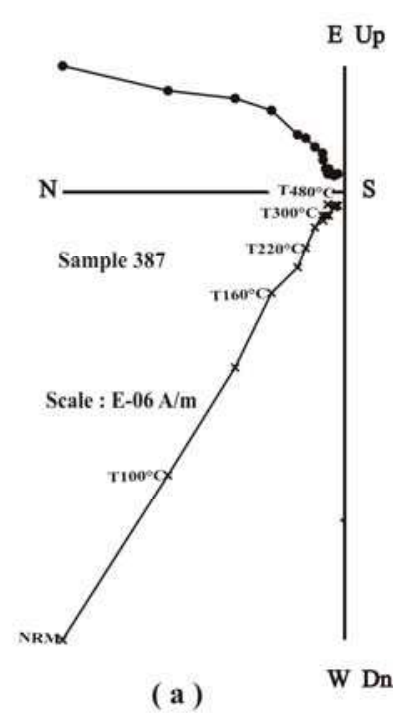

(a)

Fig. 4a. Orthogonal vector plots (filled circles: horizontal plane, crosses: vertical plane), in geographic coordinates for Pliocene samples 387 and 688

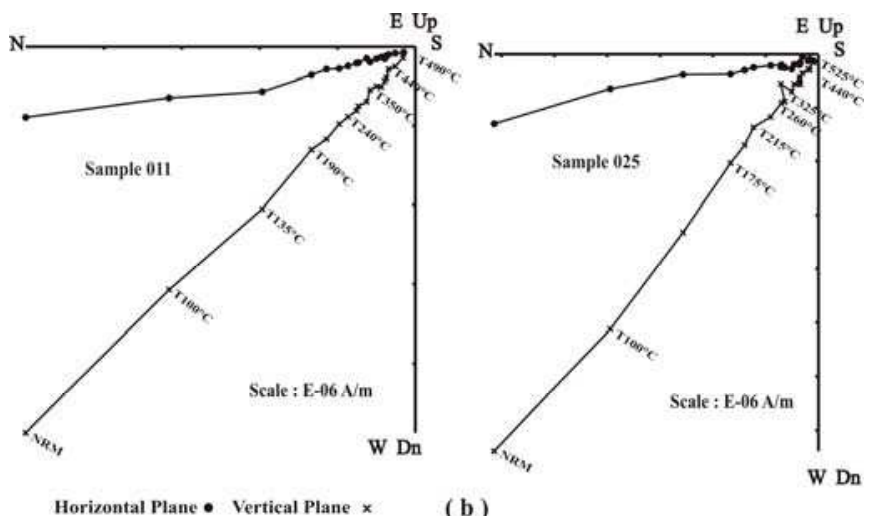

Fig. 4b. Messinian samples 11 and 25. See caption of fig. $4 \mathrm{a}$

In order to determine the acquisition age of this magnetization, paleomagnetic tests were considered when possible for each site. The conglomerate test was possible for two sites: site 8 (Lower Miocene), and site 32 (Tortonian). Within the conglomerate, the ChRM directions from matrix samples are relatively grouped (Fig $5 a$ - site 8 and Fig $5 b$ - site 32, matrix) while ChRMs with random orientation have been obtained for pebbles samples. This conglomerate test provides the evidence that the matrix ChRM (with reversed polarity - site 
8 - and with normal polarity - site 32) is the primary magnetization. The fold test can be applied also only in few sites. Though this fold test never gives statistically significant (McElhinny, 1964) result here, the fact that the bedding correction increases the scattering in some sites (Fig. $5 d$ - station k, sites 47-48-62-63) argues rather in favor of a secondary character of the magnetization for these sites. This secondary character is reinforced by the results obtained by an attempt of magnetostratigraphy study performed in the "Djebel Menni" area (Western Chelif basin). This study has been carried out on 47 samples regularly distributed along a continuous section of well known stratigraphical ages (Belkebir et al., 2008) corresponding to a period including magnetic Earth field reversals (Langhian, Serravallian and Tortonian). The only normal polarity obtained for the ChRM (Fig. 6) indicates that these levels were affected by a remagnetization.

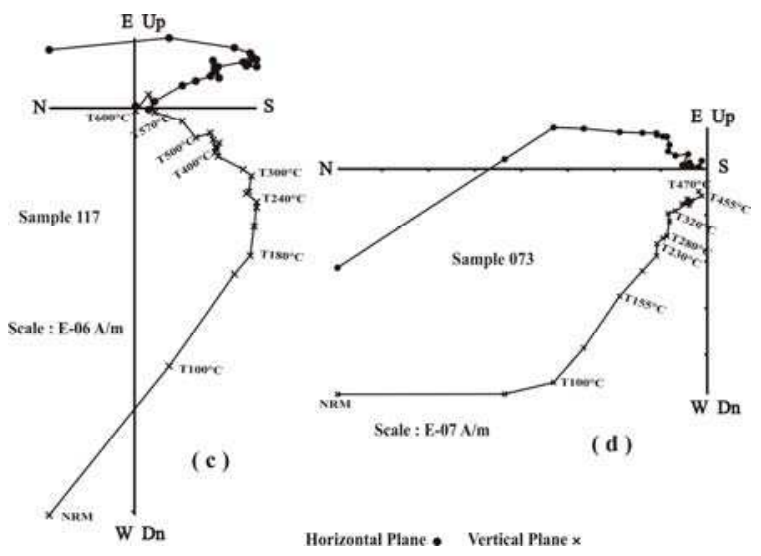

Fig. 4c and 4d. c) Messinian sample 117; d) Tortonian sample 73. See caption of fig. 4a
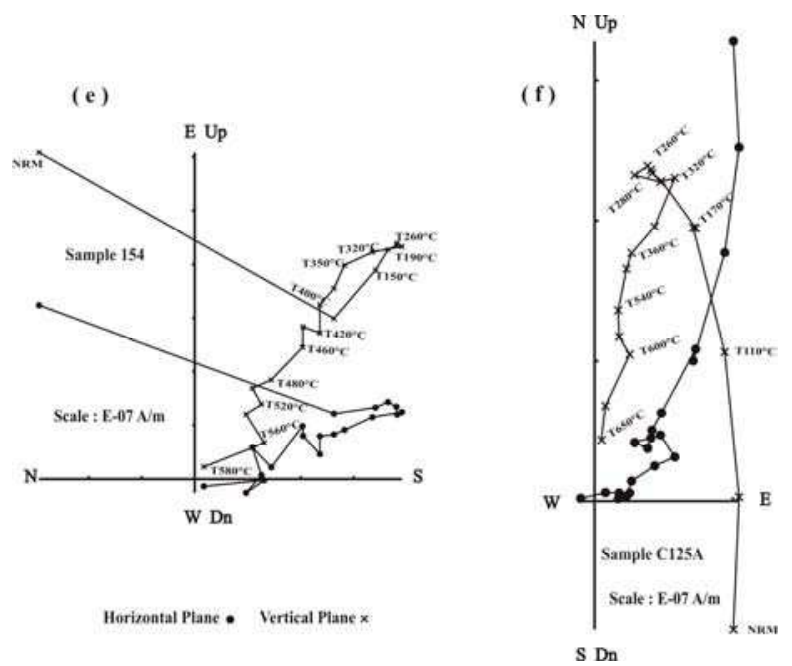

Fig. 4 e and 4f. Lower Miocene sample 154, and 125. See caption of fig. 4a 


\section{Station c (Site 8)}
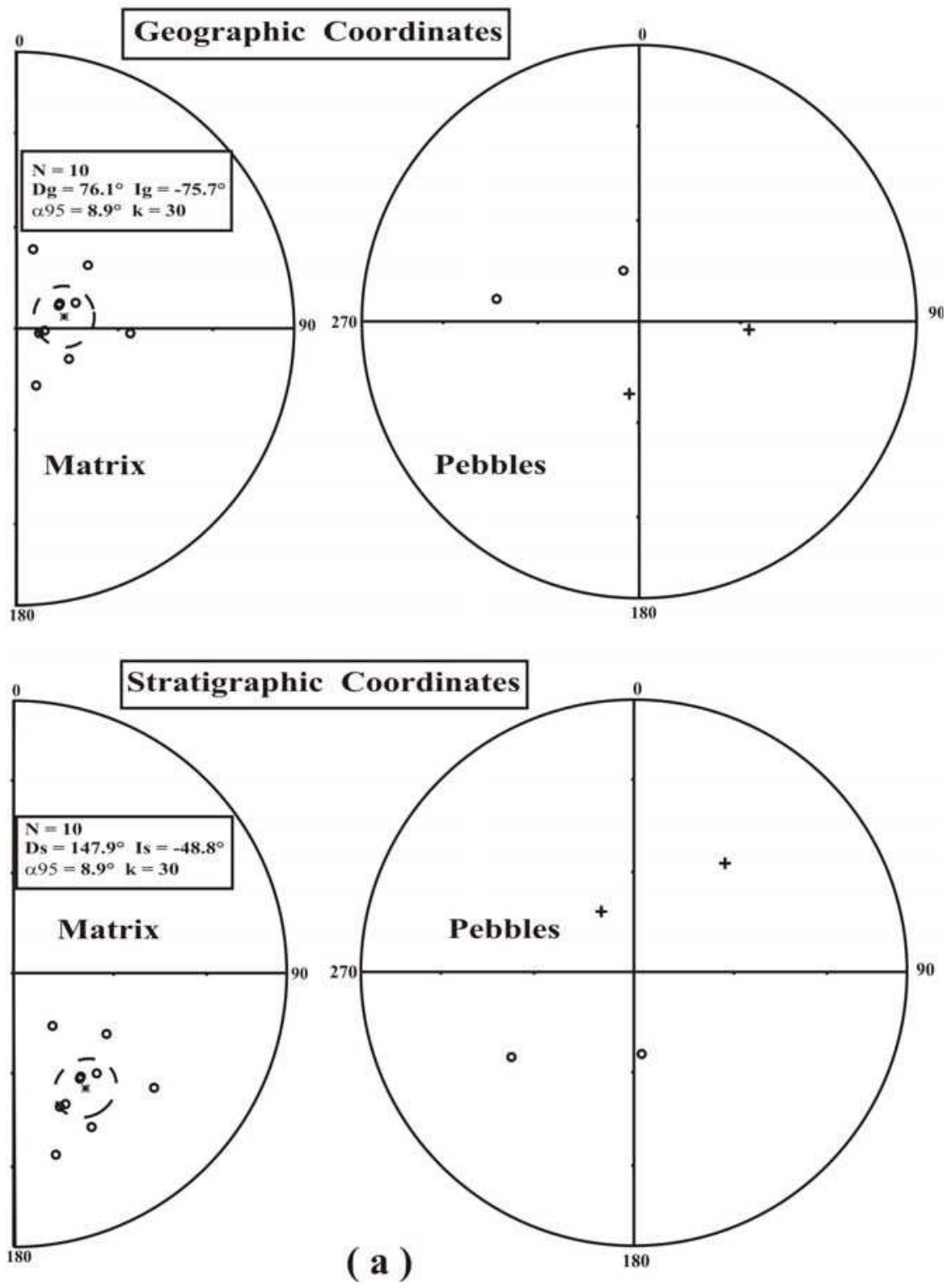

Fig. 5a. Mean paleomagnetic directions and their associated $95 \%$ confidence cone, before and after bedding correction for station c (site 8), (stereographic projection - open symbols and dotted line (confidence cone) for the upper hemisphere; full symbols and continuous line (confidence cone) for the lower hemisphere) 
Station i (Site 32)
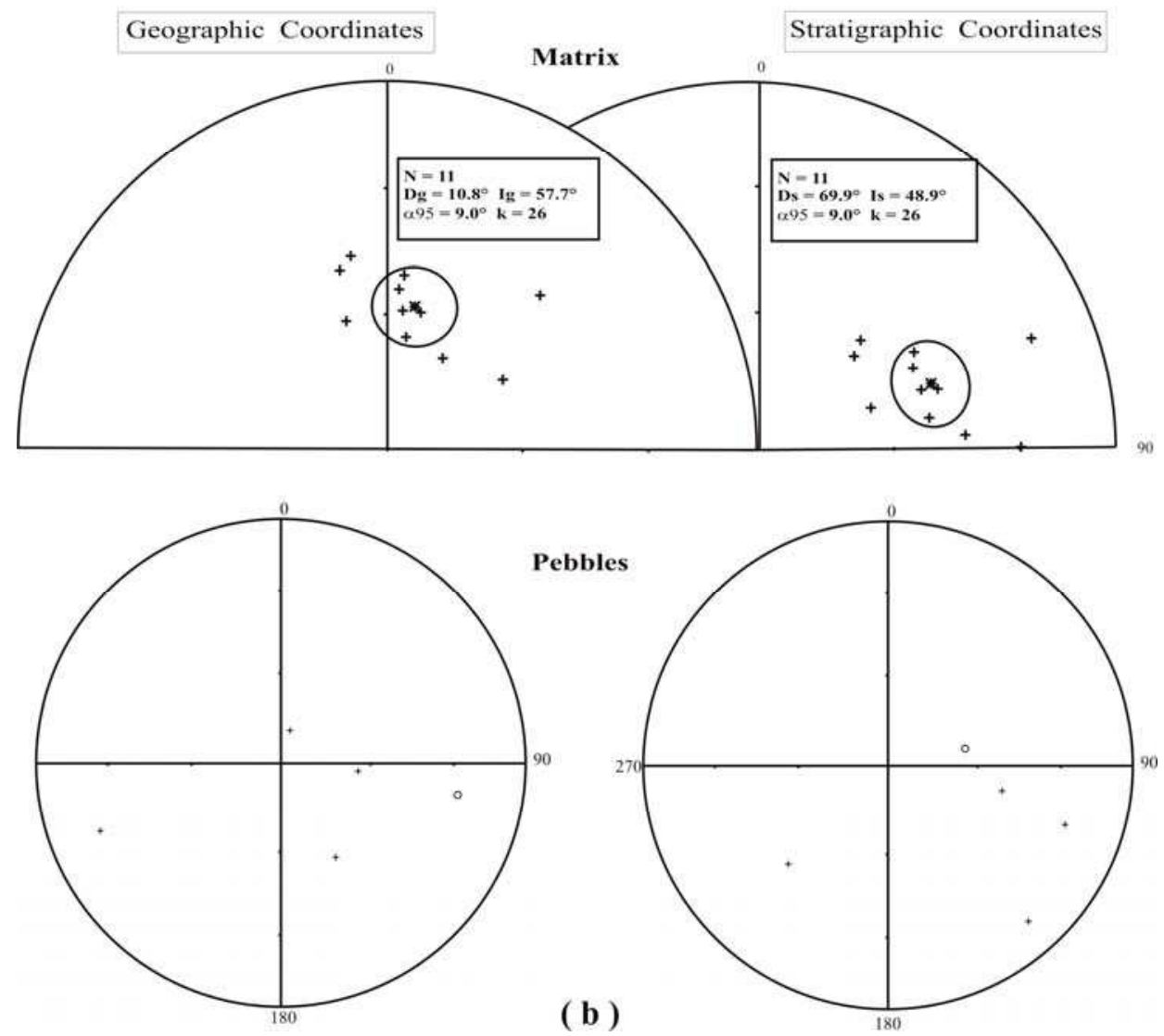

Fig. 5b. Station i (sites 32). See caption of fig. 5a

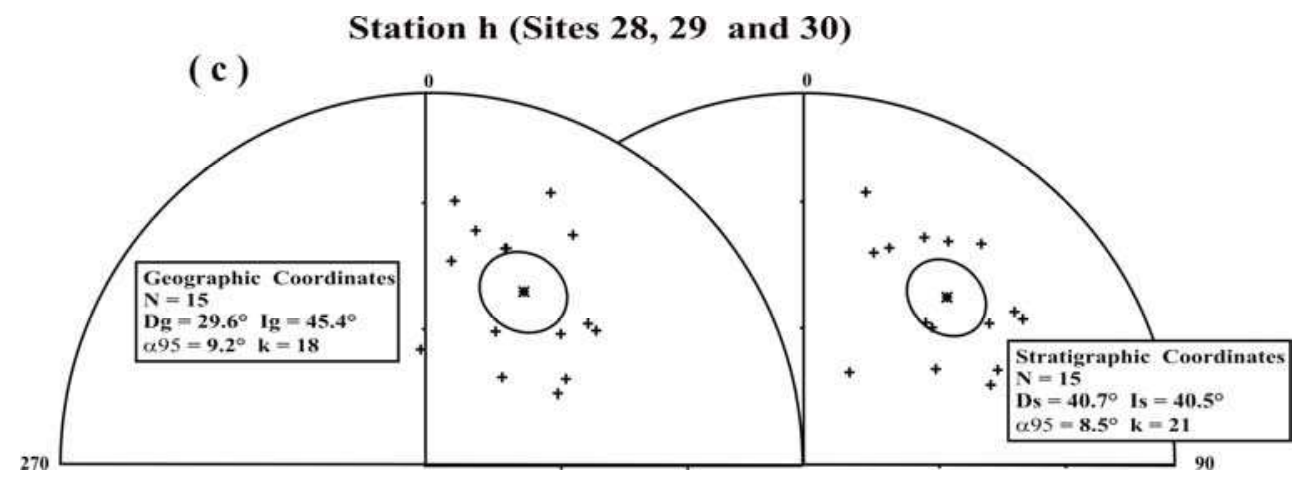

Fig. 5c. Station h (sites 28-29-30). See caption of fig. 5a 


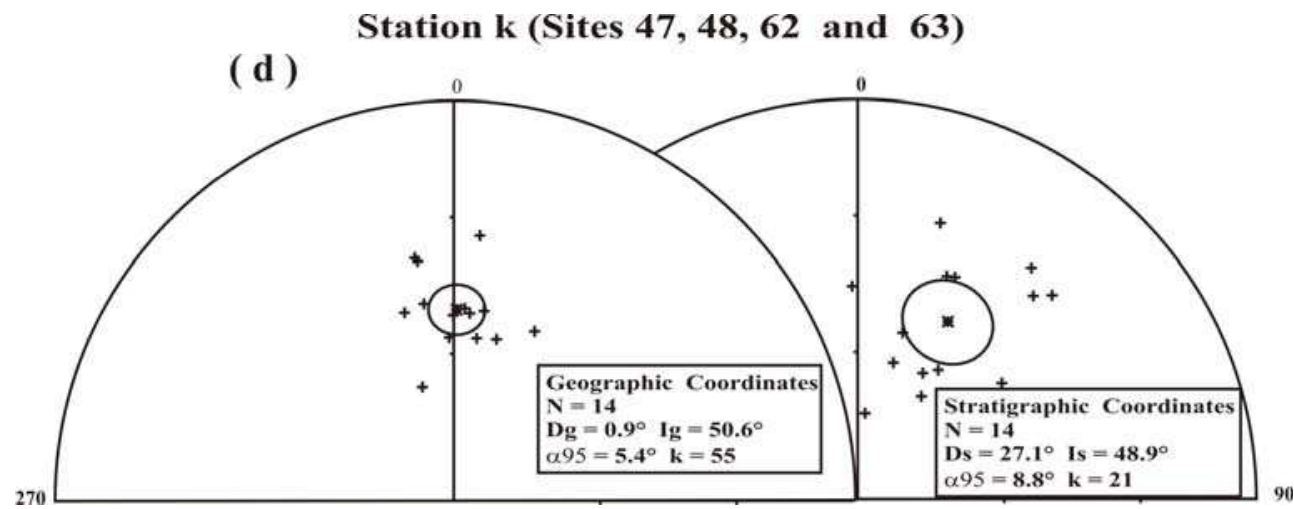

Fig. 5d. Station k (sites 47, 48, 62, 63). See caption of fig. 5a

\section{“Djebel Méni" Section}

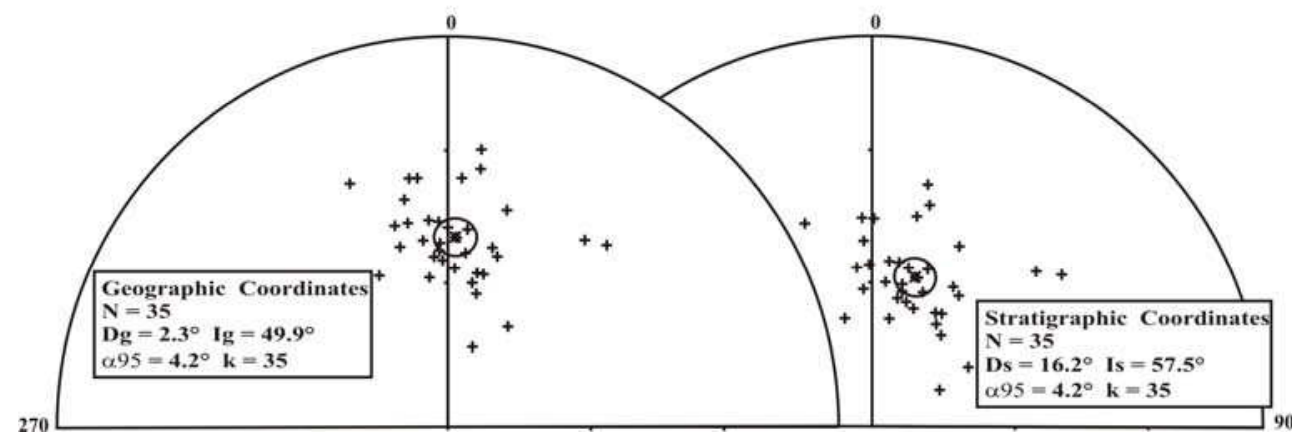

Fig. 6. ChRM directions determined in the "Djebel Meni" section. See caption of fig. 5a

\section{Magnetic fabric results}

Previous studies of depositional AMS in sediments have shown that the shape and orientation of the magnetic fabric can be related to different sedimentological processes during the deposition of particles from suspension in water (Ellwood, 1980; Rees, 1965; Rees et al., 1968; Rees \& Woodall, 1975; Weiler, 2007). The initial sedimentary fabrics are generally determined by gravity and currents. Typical primary depositional fabric tends to be characterized by vertical or subvertical minimum axis. In the second case, the deviation of this axis (after bedding correction) from the vertical is related to the effects of currents (imbrication); the magnetic foliation generally slightly dips toward the current sense. The maximum axis can be parallel or perpendicular to the current direction, according to the shape of the particles and the velocity of the flow. The best approach to determine the paleocurrents direction is therefore to look for the deviation sense of the minimum axis relatively to the vertical in stratigraphical coordinates.

This initial sedimentary fabric may have been modified if the rock was affected by a deformation. During a progressive deformation, first the maximum axis becomes 
perpendicular to the shortening direction within the stratification plane (intersection lineation) and later the minimum axis moves to a direction parallel to this shortening direction (e.g. Graham, 1978; Weiler, 2007). For a stronger deformation, the orientation of all the principal susceptibility axes becomes similar to that of the corresponding strain axes.

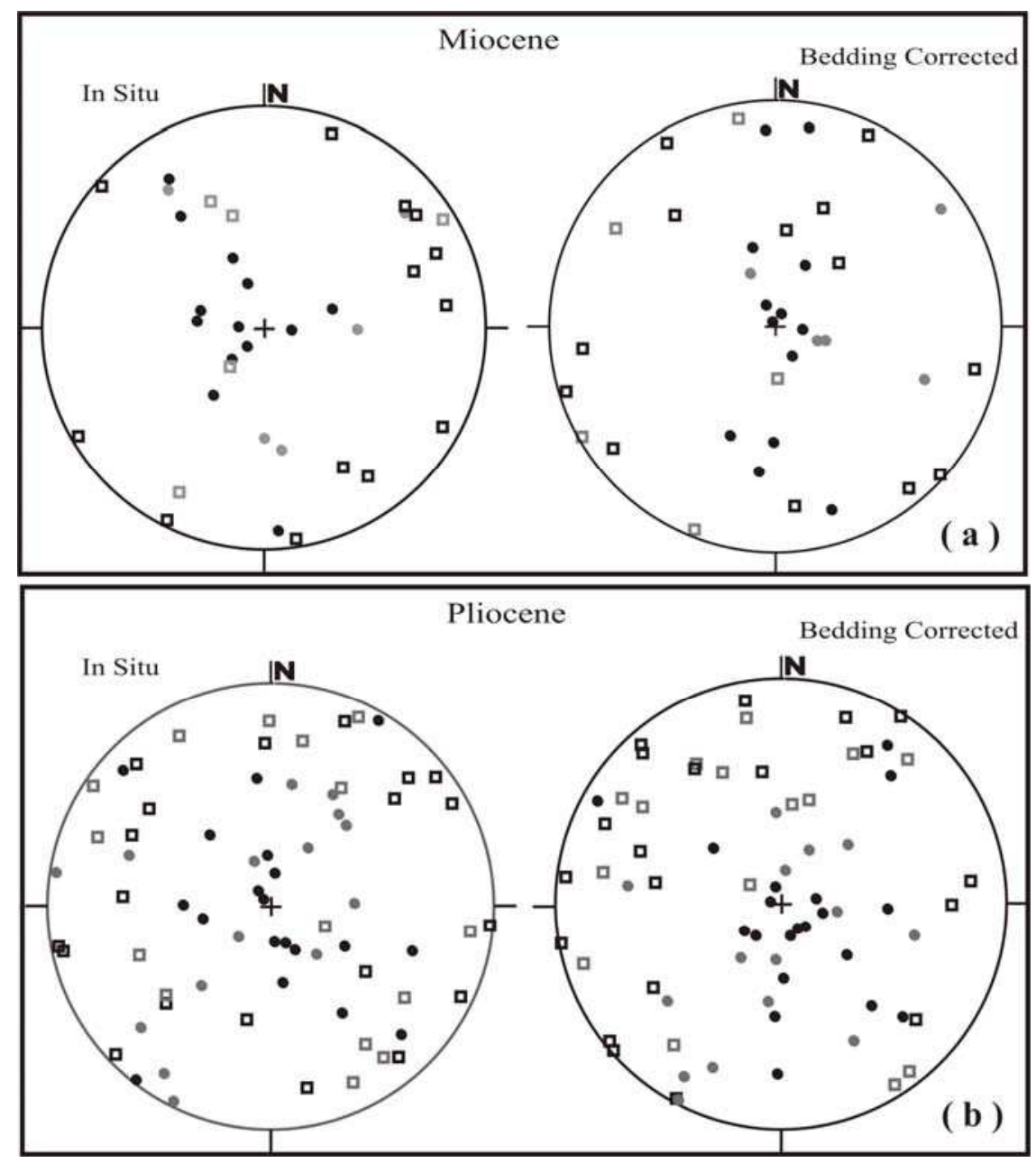

Fig. 7. Principal mean maximum (squares) and minimum (circles) susceptibility axes before and after bedding correction obtained in (a) the Lower Miocene, Tortonian and Messinian and (b) the Pliocene sites (stereographic projection in the lower hemisphere). Gray symbols (associated confidence zone at $95 \%$ of $20^{\circ}$ or larger than $20^{\circ}$ ), black symbols (associated confidence zone at $95 \%$ lower than $20^{\circ}$ )

The AMS in low field, measured using a KLY3 Kappabridge (AGICO, Brno), yields the principal magnetic susceptibility axes: maximum $K_{1}$ (magnetic lineation), intermediate $K_{2}$ and minimum $K_{3}$ (pole of the magnetic foliation). The Jelinek (1981) intensity $P^{\prime}$ and shape $T$ 
(possibly varying from +1 for uniaxial oblate fabric to -1 for uniaxial prolate fabric) parameters were used to describe the magnetic fabric. The data for a group of samples were analyzed using normalized tensor variability (Hext, 1963; Jelinek, 1978). AMS was measured on 344 specimens. For the Lower Miocene, Tortonian and Messinian sites, the mean susceptibility varies between 29 and 641 in 10-6 SI (mean 203.10-6 SI). The uncertainty (confidence zone at 95\%) related to measurement is moderate (radius of less than $20^{\circ}$ for the axes orientation) for about $75 \%$ of the samples. The results from the different samples of a same site are coherent in most sites and the principal axes mean direction per site is significantly defined (confidence zone at $95 \%$ of the mean axes lower than $20^{\circ}$ ) for 14 of the 18 sites. The minimum axes are scattered around the stratification pole and the maximum axes around the stratification plane (Fig. 7a). For the mean tensor fabric per site (Fig. 8), the anisotropy degree is weak ( $\mathrm{P}^{\prime}$ parameter between 1.001 and 1.036 with a mean value of 1.012) and the shape of the susceptibility ellipsoid is dominantly oblate (T between -0.47 and 0.91 with a mean value of 0.40 ). The two sites with a prolate mean fabric correspond to sites with incoherent fabric of their different samples and this prolate shape could be an artifact.

For the Pliocene sites, the mean susceptibility is mostly low (between 0.06 and 1481 in 10-6 SI with a mean of 128.10-6 SI). The uncertainty (confidence zone at 95\%) related to measurement is moderate (radius of less than $20^{\circ}$ for the axes orientation) for about $70 \%$ of the samples, but the results in the different samples of a same site are less coherent than for the Lower Miocene, Tortonian and Messinian sites, and the principal axes mean direction per site is precisely defined for only 13 of the 35 Pliocene sites. For the 22 other Pliocene sites, the confidence zone at $95 \%$ of the axes are larger than $20^{\circ}$ and the mean results have to be considered with care. In the Pliocene sites, the minimum axes are also scattered around the stratification pole and the maximum axes around the stratification plane (Fig. $7 \mathrm{~b}$ ). For the mean tensor fabric per site (Fig. 8), the anisotropy degree is weak ( $\mathrm{P}^{\prime}$ parameter between 1.002 and 1.048 with a mean value of 1.013) and the shape of the susceptibility ellipsoid is dominantly oblate ( $\mathrm{T}$ between -0.53 and 0.98 with a mean value of 0.20 ).

Though the weak anisotropy and the low susceptibility of the studied rocks, reliable magnetic fabric has been obtained for half of the sites. For the other sites, AMS results have to be considered with more care. However these sites give mostly relatively similar axes orientation as their neighboring reliable sites. Their results were therefore not discarded but will be presented with a gray symbol on the figures of the discussion to underline the higher uncertainty of these data.

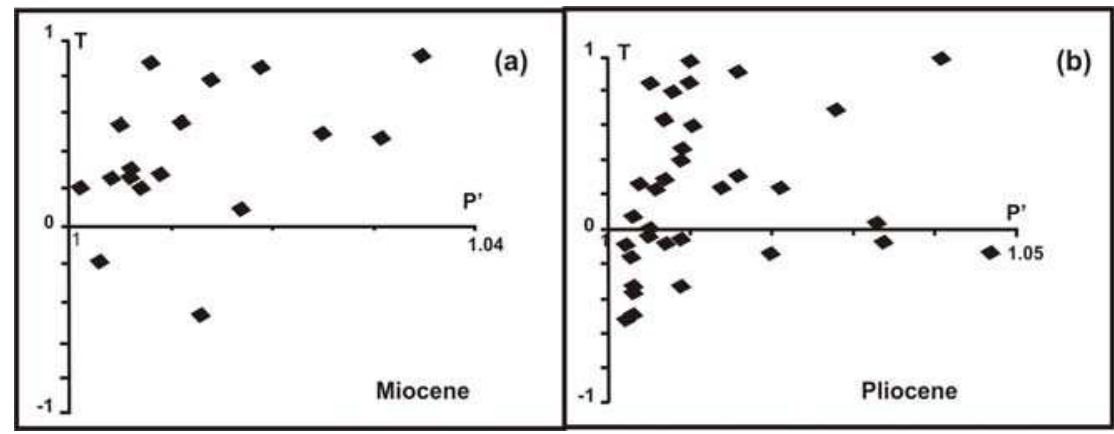

Fig. 8. P' parameter as a function of T parameter (Jelinek, 1981) 


\section{Discussion}

\subsection{Paleomagnetic data}

The lack of well-established age of magnetization acquisition for some sites makes the interpretation of the paleomagnetic data very difficult. Aïfa et al. (1992) obtained negative fold test in the area of Beni Rached and El Abadia and therefore concluded for a postfolding remagnetization. In the present work, we came to the same conclusion with the section of well-known Langhian to Tortonian age (Belkebir et al., 2008; Bessedik et al., 2002) in the "Djebel Meni" area (in the western part of the Chelif basin) because of the obtained uniform normal polarity. However, in the sites 44 to 46 , both normal and reversed polarities have been obtained. Moreover, in two similar conglomeratic facies sites (8 and 32), the conglomerate test indicates a primary magnetization. We therefore tried to obtain more information about the magnetization age in the different studied sites.

Because of the low proportion of reliable paleomagnetic results obtained in most studied sites, when possible we grouped as "stations" the results from several neighboring sites corresponding to formations of the same age. At the total, 14 mean paleomagnetic data (stations) were retained (Table 1).

In three neighboring sites, normal and reversed polarities have been obtained (in equal proportion in the site 44 , mainly normal in the site 45 and mainly reversed in the site 46 ). An indeterminate $\left(\gamma_{c}=24.8^{\circ}\right.$ and $23.0^{\circ}$ after and before bedding correction, respectively) reversal test (McFadden \& McElhinny, 1990) has been obtained for this group of sites (station $j$, Fig. 10) though neighboring mean normal and reversed directions $\left(\gamma=6.3^{\circ}\right.$ and $7.6^{\circ}$ after and before bedding correction, respectively). This is due to the very high scattering of the reversed directions and only the normal polarity directions will be thus considered for this station $j$ (Table 1). On the other hand, the obtained polarity in the sites 44 and 46 is not homogeneous in a same bed. This unhomogeneity shows that at least one of the polarities is related to a remagnetization. This can be due only to unhomogeneity of the rock characteristics that is likely of sedimentological (e.g. local variation of permeability) or brittle tectonic origin. The remagnetization process in such a basin cannot be thermal and the obtained Tunb during thermal demagnetization also exclude a viscous magnetic overprint. It is therefore chemical, probably related to fluids circulation (Henry et al., 2004a and references therein).

The station $k$ is the only one giving a statistically significant fold test. The progressive unfolding (Fig. 9) clearly indicates a postfolding remagnetization. This fold test is significant at $95 \%$ (ratio of the Fisher's - 1953 - precision parameter $\mathrm{k}$ after/before bedding correction of 2.56 for a critical value of 1.84 - McElhinny, 1964). The conglomerate test shows that the magnetization is primary in the stations $c$ and $i$ (Fig. 5a and 5b). 3 stations $(e, k$ and $m$ ) show before bedding correction a magnetization direction coinciding with the recent magnetic field (Table 1), and their result was therefore interpreted as a postfolding remagnetization. For the station $k$, the secondary character of the magnetization was already shown by the fold test. Finally, because of the aberrant value of magnetization inclination in some sites during part of a progressive unfolding, we compared (Fig. 11) the obtained inclination of the paleomagnetic direction before and after bedding correction with the expected inclination of the Earth magnetic field for the Upper Neogene in the Chelif basin (of the order of $50^{\circ}$ Besse and Courtillot, 2002). That indicates a postfolding remagnetization for the paleomagnetic directions of the stations $a$ (inclination of $45^{\circ}$ and of $29^{\circ}$ before - $I g$ - and after - Is- dip correction, respectively), $\boldsymbol{d}\left(I g=53^{\circ}\right.$ and $\left.I s=30^{\circ}\right)$ and $h\left(I g=45^{\circ}\right.$ and $\left.I s=40^{\circ}\right)$, but a prefolding magnetization for the stations $\boldsymbol{b}\left(I g=68^{\circ}\right.$ and $\left.I_{s}=55^{\circ}\right), g\left(I g=62^{\circ}\right.$ and $\left.I_{s}=56^{\circ}\right), \boldsymbol{j}$ 
$\left(I g=61^{\circ}\right.$ and $\left.I s=56^{\circ}\right)$ and $l\left(I g=60^{\circ}\right.$ and $\left.I s=50^{\circ}\right)$. Finally only the two stations $f$ and $\boldsymbol{n}$ have paleomagnetic direction of undetermined age. The retained paleomagnetic declination for each station is presented on a map (Fig. 12), which shows different dominant orientations.

- The orientation A corresponds to 6 declinations indicating strong clockwise rotation. It is well-represented in a large northeastern part of the studied area. Four of these declinations (stations $\boldsymbol{b}, \boldsymbol{g}, \boldsymbol{i}$ and $\boldsymbol{j}$ ) represent a prefolding magnetization (i.e. very likely a primary magnetization because of the synsedimentary age of the basin structuration see magnetic fabric data section) and one is postfolding $(\boldsymbol{h})$. It is important to notice that, for the other station $(f)$ of this group $\mathbf{A}$, with undetermined age of magnetization, the rotation is also clockwise, whatever the assumed magnetization age. The only difference is the magnitude of the rotation, which is a little bit lower for a postfolding remagnetization hypothesis. A seventh declination (station $l$ ), again corresponding to a primary magnetization, indicates clockwise rotation of smaller magnitude and could be associated with the orientation A. The results obtained by (Aiffa et al., 1992) in 3 sites at Beni Rached area and 2 sites at El Abadia area also belong to the orientation A. They correspond to magnetic overprint and evidenced a clockwise rotation of 10 to $25^{\circ}$ (Fig. 12).

- The orientation $\mathbf{B}$ on the contrary indicates counterclockwise rotation. It has been found in 3 stations ( $\boldsymbol{a}, \boldsymbol{c}$ and $\boldsymbol{d}$ ), all corresponding to area close to the main southeastern border-faults of the basin pointed out by the gravimetric data (Abtout et al., 2009; Idres et al., 1996).

- No significant rotation is associated with the declination C obtained in 3 stations $(e, k$ and $m$ ). However, this orientation also corresponds to postfolding remagnetization and assumption of a pre-remagnetization rotation cannot be excluded. These data therefore do not yield to usable information about the structural evolution of the basin.

- The declination $\mathbf{D}$ corresponds to a single station ( $n)$, located close to a secondary fault (Fig. 1). It highlights a very strong rotation. The fact that this datum is well-defined (Table 1) and obtained from 11 different specimens distributed on a large area (more than $100 \mathrm{~m}^{2}$ ) shows that this declination is not an artifact. This rotation is attributed to a very local deformation associated to this secondary fault, and thus cannot be used as information for improving the structural evolution model of the basin.

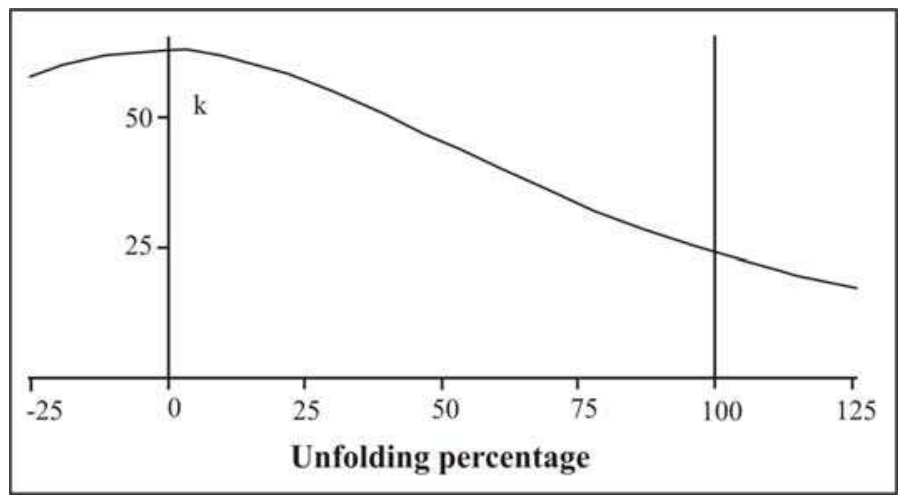

Fig. 9. Variation of the Fisher's (1953) precision parameter $k$ during progressive unfolding for the station $k$ (sites 47-48-62-63) 


\begin{tabular}{|c|c|c|c|c|c|c|c|c|c|c|}
\hline \multirow{2}{*}{ S } & \multirow{2}{*}{ Sites } & \multirow{2}{*}{$\mathrm{N}$} & \multicolumn{4}{|c|}{ Geographic coordinates } & \multicolumn{3}{|c|}{ Stratigraphic coordinates } \\
\cline { 4 - 11 } & & & $\mathrm{D}\left(^{\circ}\right)$ & $\mathrm{I}\left(^{\circ}\right)$ & $\mathrm{k}$ & $\alpha_{95}\left(^{\circ}\right)$ & $\mathrm{D}\left(^{\circ}\right)$ & $\mathrm{I}\left(^{\circ}\right)$ & $\mathrm{k}$ & $\alpha_{95}\left(^{\circ}\right)$ \\
\hline $\mathbf{a}$ & $\mathbf{1 - 2 - 6 - 7}$ & 15 & 341.7 & 45.2 & 24 & 8.0 & 342.6 & 29.1 & 21 & 8.6 \\
\hline $\mathbf{b}$ & $\mathbf{4 - 5}$ & 4 & 18.2 & 67.9 & 39 & 14.8 & 46.8 & 54.6 & 40 & 14.7 \\
\hline $\mathbf{c}$ & $\mathbf{8}$ & 10 & 76.1 & -75.7 & 30 & 8.9 & 147.9 & -48.8 & 30 & 8.9 \\
\hline $\mathbf{d}$ & $\mathbf{1 0}$ & 7 & 155.2 & -52.7 & 47 & 8.9 & 175.8 & -29.6 & 47 & 8.9 \\
\hline $\mathbf{e}$ & $\mathbf{1 6 - 1 7}$ & 6 & 5.4 & 56.2 & 27 & 13.2 & 343.2 & 47.3 & 17 & 16.7 \\
\hline $\mathbf{f}$ & $\mathbf{2 2 - 2 3}$ & 6 & 224.1 & -46.8 & 11 & 20.8 & 251.1 & -50.1 & 10 & 21.8 \\
\hline $\mathbf{g}$ & $\mathbf{2 5}$ & 5 & 11.2 & 62.4 & 22 & 16.7 & 54.2 & 56.4 & 22 & 16.7 \\
\hline $\mathbf{h}$ & $\mathbf{2 8 - 2 9 - 3 0}$ & 15 & 29.6 & 45.4 & 18 & 9.2 & 40.7 & 40.5 & 21 & 8.5 \\
\hline $\mathbf{i}$ & $\mathbf{3 2}$ & 11 & 10.8 & 57.6 & 26 & 9.0 & 69.8 & 48.9 & 26 & 9.0 \\
\hline $\mathbf{j}$ & $\mathbf{4 4 - 4 5 - 4 6}$ & 9 & 0.1 & 61.2 & 35 & 8.8 & 17.0 & 56.5 & 20 & 11.8 \\
\hline $\mathbf{k}$ & $\mathbf{4 7 - 4 8 - 6 2 - 6 3}$ & 16 & 1.2 & 50.5 & 62 & 4.7 & 26.7 & 49.7 & 24 & 7.7 \\
\hline $\mathbf{1}$ & $\mathbf{6 0 - 6 1}$ & 6 & 14.9 & 60.5 & 26 & 13.3 & 5.9 & 50.5 & 13 & 19.2 \\
\hline $\mathbf{m}$ & $\mathbf{6 4 - 6 5}$ & 4 & 1.2 & 49.4 & 53 & 12.7 & 78.0 & 59.8 & 41 & 14.5 \\
\hline $\mathbf{n}$ & $\mathbf{7 1}$ & 11 & 176.4 & 51.2 & 91 & 4.8 & 236.5 & 55.2 & 46 & 6.8 \\
\hline
\end{tabular}

Table 1. Stations, corresponding sites, number of samples $\mathrm{N}$, magnetic declination $\mathrm{D}$, magnetic Inclination I and corresponding Fisher's (1953) parameters k and $\alpha_{95}$ in geographic and stratigraphic coordinates (D, I and $\alpha_{95}$ in degrees)

\section{Station $\mathbf{j}$ (Sites 44,45 and 46$)$}

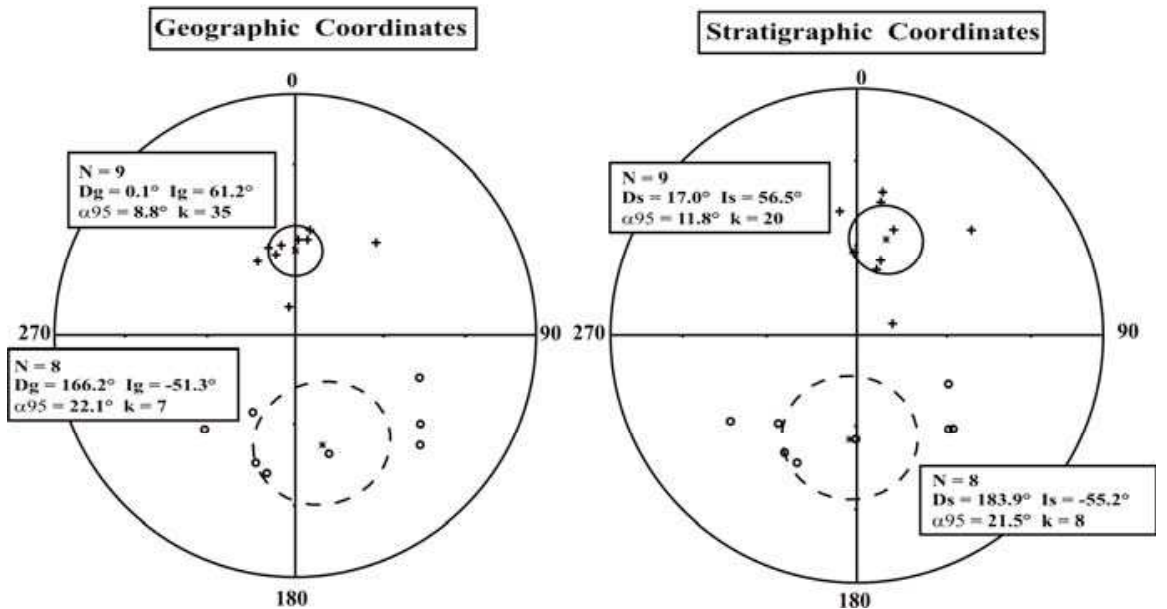

Fig. 10. Mean paleomagnetic directions and their associated $95 \%$ confidence cone (for the normal and reversed directions), before and after bedding correction for station $\mathrm{j}$ (sites 4445-46), (See caption of fig. 5a) 


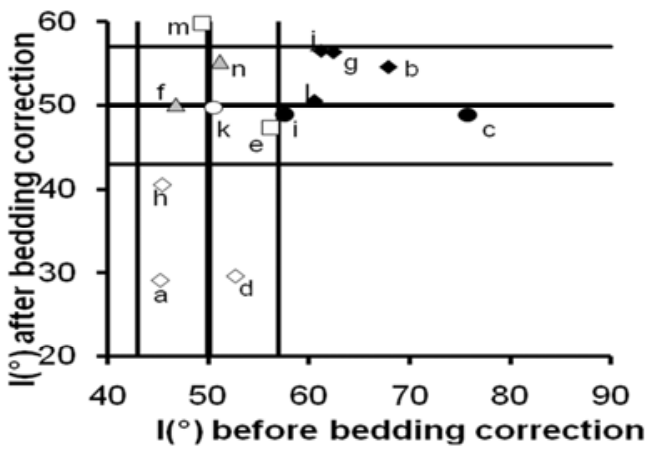

Fig. 11. Inclination after bedding correction versus inclination before bedding correction (in absolute values). Expected inclination around $50^{\circ}$ (calculated after Besse \& Courtillot, 2002) with an uncertainty window of $7^{\circ}$ (corresponding to the uncertainty of $2^{\circ}$ on the paleomagnetic pole - calculated after Besse \& Courtillot, 2002 - and an arbitrary additional uncertainty of $5^{\circ}$ associated with the paleomagnetic data). Prefolding (full symbols), undated (gray triangles) and postfolding (open symbols) magnetizations. Magnetization acquisition age according to paleomagnetic tests (circles), coincidence with the recent field (squares) and inclination value (diamonds)

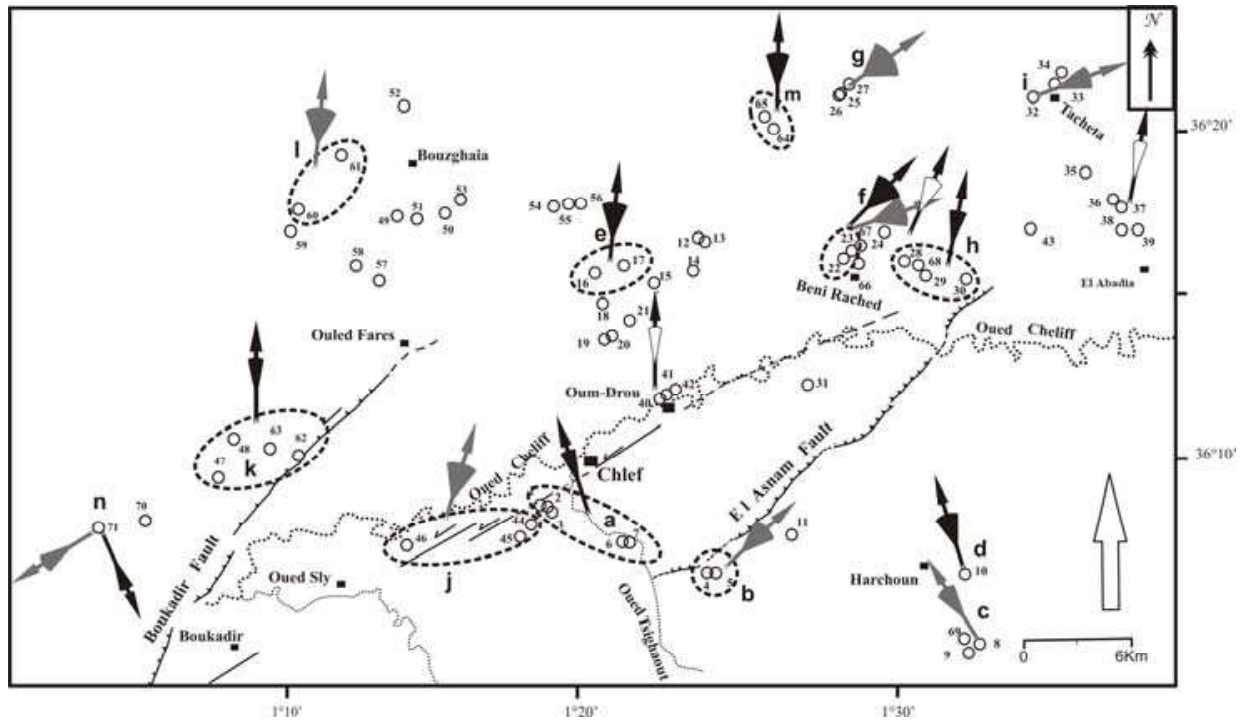

Fig. 12. Retained paleomagnetic declination for the different stations with uncertainty associated with the rotation amplitude (Desmarest, 1983). Gray and black small arrows correspond to prefolding and postfolding magnetizations respectively (gray and black arrows in the stations $\mathrm{f}$ and $\mathrm{n}$ with undetermined magnetization age). The partly open small arrows represent the Aiifa et al. (1992) data. The large open arrow on the bottom right indicates the expected magnetization direction after Besse and Courtillot (2002) 
For the structural interpretation at the basin scale, only the declinations $\mathbf{A}$ and $\mathbf{B}$ can thus be considered. The declination $\mathbf{A}$ has been obtained in widespread sites and is interpreted as resulting from the clockwise rotation of large blocks, as in a "bookshelf" model (Biggs et al., 2006 and reference therein). The uncertainty about the rotation amplitude has been determined according to the Demarest (1983) procedure. The stations $g$ and $i$ with prefolding magnetization of Tortonian age, recorded clockwise rotations of $\sim 54 \pm 33.5^{\circ}$ and $\sim 70 \pm 16^{\circ}$ respectively, giving a mean of $\sim 62^{\circ}$ for the north-eastern part of the basin. That corresponds to a rotation rate between $\sim 5^{\circ} / \mathrm{My}$ and $8.6^{\circ} / \mathrm{My}$ according to the age, not precisely known, of the studied level within the Tortonian (between 11.6 and $7.2 \mathrm{Ma}-$ Gradstein et al., 2004). Whereas for the stations $\boldsymbol{b}$ and $\boldsymbol{j}$ with prefolding magnetization of Messinian age, the obtained clockwise rotations of $\sim 47 \pm 20.5^{\circ}$ and $\sim 17 \pm 18.6^{\circ}$ respectively, gives a mean of $\sim 32^{\circ}$ as rotation for the central part of the basin, corresponding to a rotation rate of $\sim 4.4^{\circ} / \mathrm{My}$ to $6^{\circ} / \mathrm{My}$ according to the age, not precisely known, of the studied level within the Messinian (between 7.2 and 5.3 Ma - Gradstein et al., 2004).

To summarize, this area has thus undertaken clockwise rotation since the deposition of the Tortonian formation. The obtained rotation rate should be between $4.4^{\circ} / \mathrm{My}$ and $8.6^{\circ} / \mathrm{My}$ according to our data. Taking into account the large uncertainty associated with our data, these window of rotation rates is compatible with that (2.5 to $3.9 \%$ My) proposed by (Meghraoui et al., 1996) using the convergence velocity of the Africa and Eurasia plates.

Local deformation due to shearing close to the main sinistral faults gave on the contrary the counterclockwise rotation associated with the orientation B (Henry et al., 2004b).

\subsection{Magnetic fabric data}

The magnetic foliation is close to the bedding plane, mostly with a moderate imbrication angle relative to this plane. Most magnetic lineations trend NW-SE and do not have a relation with the fold axes and with the perpendicular to the regional shortening direction (Fig. 13a). In this case, it is clear that the magnetic fabric is only of sedimentary origin. Some other magnetic lineations are NE-SW oriented. We cannot exclude a tectonic effect on the fabric for these samples. However, this orientation is quite perpendicular to the NW-SE lineations. In sedimentary fabric, lineation can be parallel or perpendicular to the deposit current direction, and it is then more probable that the NE-SW lineations are also related to paleocurrents.

To determine the direction of the paleocurrents, the most reliable approach is based on the imbrication. This direction is in the plane including the pole of the magnetic foliation (minimum susceptibility axis) and the pole of the stratification (Fig. 13a). On a projection in the lower hemisphere, the sense of the current is assumed to be opposite to the sense of the deviation of the minimum axis relative to the stratification pole. About $1 / 4$ of the sites do not reliably yield this direction because of too weak imbrication angle (i.e too weak angular difference between minimum axis and stratification pole). For part of the remaining sites, this direction also corresponds to the magnetic lineation, confirming the obtained paleocurrent orientation. However, the paleomagnetic data showed that at least part of the sites was affected by a rotation. To infer the initial paleocurrent direction, a correction has to be applied for this rotation and only very few sites (including two sites with large uncertainty on AMS) finally yield at the same time significant rotation and paleocurrent data. We can however remark that the obtained paleocurrent direction (Fig. 13b) for these sites is rather perpendicular to the present fold axes within the basin, except around the main fold axis where it is rather parallel to this axis. That suggests deposit currents already 
in relation with the basin structure, toward the basin synclines axes on the border and parallel to basin main syncline axis in the middle, and therefore an early occurrence of this structure.

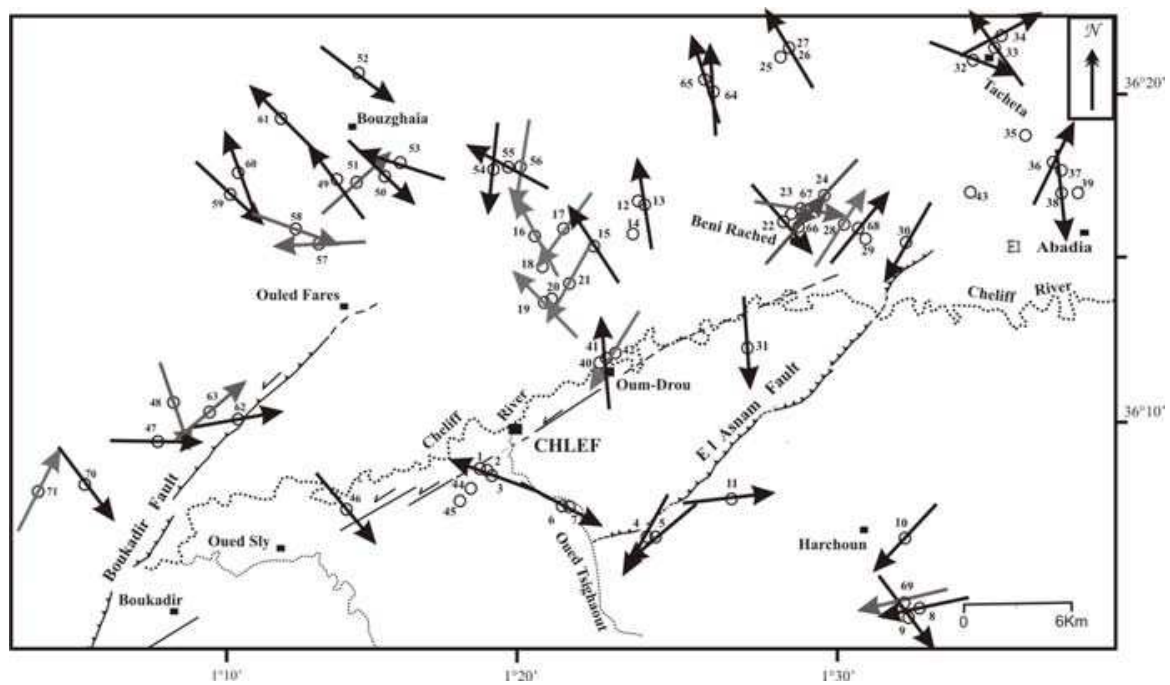

Fig. 13a. Paleocurrents directions in the different sites without correction of the rotation inferred from paleomagnetic data. The gray arrows correspond to sites with large uncertainty on the mean magnetic fabric per site

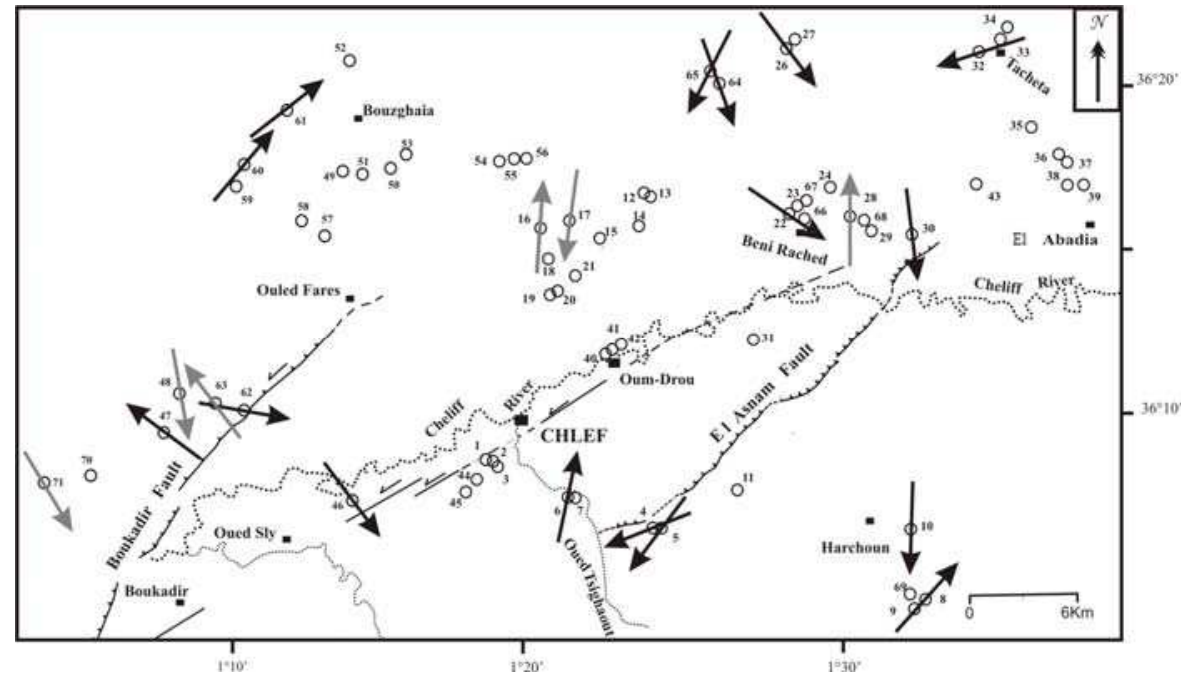

Fig. 13b. Paleocurrents directions in the different sites after correction of the rotation inferred from paleomagnetic data. The gray arrows correspond to sites with large uncertainty on the mean magnetic fabric per site 


\subsection{Implication for the structural evolution and modeling}

On the one hand, several studies (Thomas 1985, Meghraoui et al. 1986, Neurdin-Trescartes, 1992; Meghraoui et al., 1996, Belabbes 2008) have already shown that the deformation in northern Algeria (especially in its western and central parts) is characterized by NE-SW trending folds associated with NE-SW sinistral transpressive faults. As these active structures are distributed in an E-W lengthened zone and have an "en echelon" disposition, these authors suggested the existence of hidden major deep dextral E-W faults in the northern and southern borders of this deformed zone. The existence of such E-W dextral major faults has been also proposed by (Mauffret et al., (1987), along the off-shore domain. Meghraoui et al., (1996) completed this structural model (Fig. 14) suggesting an evolution with clockwise block rotation within the Chelif basin.

On the other hand, the detailed interpretation of the aeromagnetic data (Boukerbout et al., 2008) pointed out the presence of two major deep E-W faults located north and south of the Chelif basin, and a dextral movement on these deep strike-slip faults shown by these geophysical investigations implies a general shearing in all this area. In a similar structural context, block rotation related to strike-slip faulting has been already shown (e.g. Ron et al., 1984). That exactly corresponds to our results pointing out a "bookshelf" evolution.

The new detailed interpretation of the aeromagnetic data and the new results presented here evidence these key elements of the Meghraoui et al., (1996) model of the tectonic evolution of the Chelif basin, confirming the validity of this theoretical model. The tectonic activity is presently still highlighted by movements along the present tectonic structures at the origin of several recent damage earthquakes: Tenes 1922, Ms=6; Orleansville 1954, Ms= 7; and El Asnam 1980, Mw= 7.3 (Aoudia \& Meghraoui 1995, Dewey, 1990; Philip \& Meghraoui 1983).

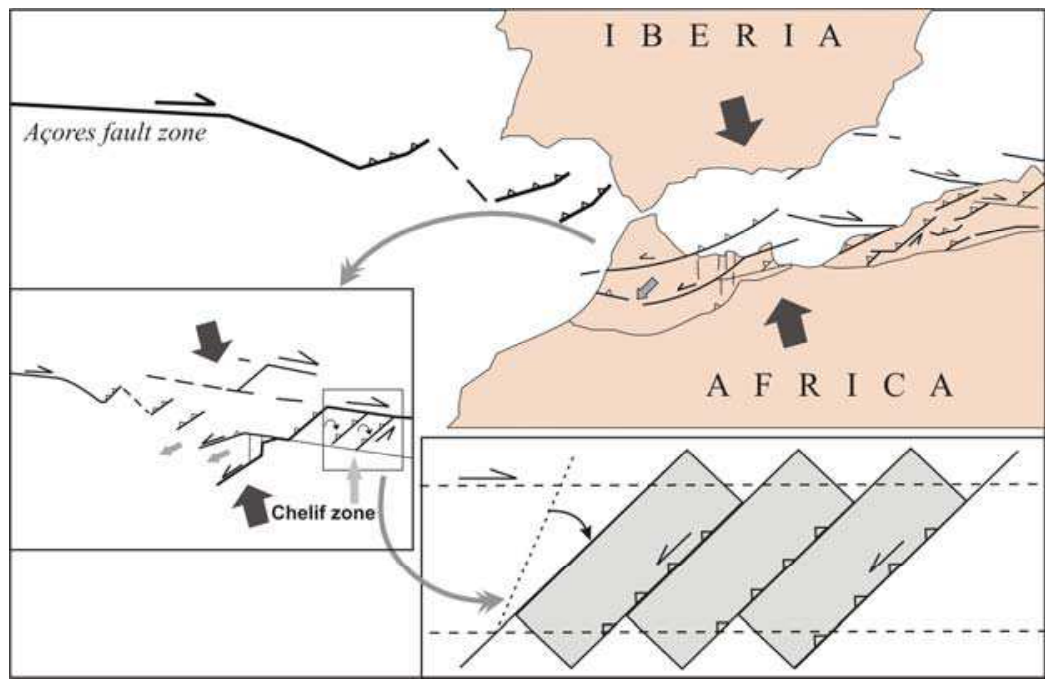

Fig. 14. Main tectonic structures of the "Gorringe-Alboran-Tell" zone of déformation. Model of deformation showing the compatibility between a NNW-SSE shortening and block movements with clockwise rotation within this zone. Kinematic model of a deformed zone with block rotation and without lateral extension, after Meghraoui et al. (1996) 


\section{Conclusion}

The relative convergence motion between the Africa and Eurasia plates is decisive for the area tectonic regime at a regional scale. The active plate boundary is situated along the coastal part of the Tellian Atlas mountains. It is highlighted by the main seismic activity related to the active tectonics, highly concentrated in the intramountainous basins (e.g. the Chelif basin). It is clear that, in the Tellian Atlas domain, the actual deformation is associated with the existence of thrust and strike- slip faults related to the convergent context. The kinematic model of block rotation highlighted here using the paleomagnetic method gives a good image of the tectonic evolution of the Chelif basin. At the scale of the plate boundary, this model can also explain the coexistence of the two kinds of structure (strike slip faulting and fault related folding) in a convergence context. Using the present results and those evidenced recently by Derder et al. (2009) in the "Mitidja" basin (central Algeria), and Derder et al. (2011) in the "Beni Haoua" area ( northern Chelif basin), it seems to be clear that all the Tellian Atlas domain is organized as tectonic blocks delimited by strike- slip faults. The relative movements of these blocks, by thrust and strike-slip faulting, are explained by clockwise rotations as in a "bookshelf" evolution. The present work evidenced the existence of such block rotations in the Chelif basin and thus confirms the validity of the Meghraoui et al. (1996) model for all the Gorringe-Alboran-Tellian Atlas area (Fig. 14).

\section{Acknowledgments}

This work was supported by the Algerian-French cooperation CMEP- PHC "Tassili" program 08MDU752 and we are very grateful to the Algerian DPGRF of the MESRS, and to the French Foreign Office. Special thanks to the "Chlef" local team of the CRAAG and to the civil and military authorities of the Chlef area for help on the field. Dr Toufik Abdelatif is thanked for his strong help with the manuscript.

\section{References}

Abtout, A., Boukerbout, H., Bouyahiaoui, B., Gibert, D. \& Derder, M.E.M. (2009). Gravity anomalies and structure of Chelif seismogenic basin (Algeria). International Earthquake Symposium Kocaeli, Turkey, 17-19 August 2009.

Aïfa, T., Feinberg, H., Derder, M.E.M. \& Merabet, N. (1992). Rotations paléomagnétiques récentes dans le bassin du Chéliff (Algérie). Comptes Rendus de l'Académie des Sciences Paris, 314, SII, 915-922.

Anderson, R.V. (1936). Geology in the coastal atlas of western Algeria. Memoir Geological Society of America, 4, $450 \mathrm{p}$.

Aoudia, A. \& Meghraoui, M. (1995). Seismotectonics in theTell Atlas of Algeria: the Cavaignac (Abou El Hassan) earthquake of 25.08.1922 ( $\mathrm{Ms}=5.9$ ). Tectonophysics $248,263-276$.

As, J.A. \& Zijderveld, J.D.A. (1958). Magnetic cleaning of rocks in paleomagnetic research. Geophysical Journal. 1, 308-319.

Belabbes, S. (2008). Caractérisation de la déformation active par l'Interferométrie Radar (InSar) : Failles sismiques et aveugles de l'Atlas Tellien (Algérie) et du Rif (Maroc) le long de la limite des plaques Afrique -Eurasie. Doct. Thesis, Univ. Louis Pasteur Strasbourg-I, 226pp. 
Belkebir, L., Bessedik, M., Ameur-Chehbeur, A. \& Anglada, R. (1996). Le Miocène des bassins nord-occidentaux d'Algérie: biostratigraphie et eustatisme. Elf Aquitaine Editions, Pau, 16, pp. 553-561.

Belkebir, L., Labdi, A., Mansour, B., Bessedik, M. \& Saint Martin, J.P. (2008). Biostratigraphie et lithologie des séries serravallo-tortoniennes du massif du Dahra et du bassin du Chélif (Algérie). Implications sur la position de la limite serravallo-tortonienne. Geodiversitas, 30 (1).

Bessedik, M., Belkebir, L. \& Mansour, B. (2002). Révision de l'âge Miocène inférieur (au sens des anciens auteurs) des dépôts du bassin du Bas Chelif (Oran, Algérie) : conséquences biostratigraphique et géodynamique. Mémoires des Services Géologiques d'Algérie, 11, pp. 167-156.

Benouar, D. (1994). Materials for the investigation of The seismicity of Algeria and Adjacent Regions During the Twentieth Century. Annali di Geofisica, volume XXXVII, N, 4.

Besse, J. \& Courtillot, V. (2002). Apparent and true polar wander and the geometry of the geomagnetic field over the last 200 Myr. Journal of Geophysical Research, 107, 2300, doi:10.1029/2000JB000050.

Bezzeghoud, M., Dimitrov, D., Ruegg, J.C. \& Lammali, K. (1995). Faulting mechanism of the El Asnam (Algeria) 1954 and 1980 earthquakes from modelling of vertical movements. Tectonophysics 249, 249- 266.

Biggs, J., Bergman, E., Emmerson, B., Funning, G.J., Jackson, J., Parsons, B. \& Wright, T.J. (2006). Fault identification for buried strike-slip earthquakes using InSAR: The 1994 and 2004 Al Hoceima, Morocco earthquakes. Geophysical Journal International, 166, 3, 1347-1362.

Boukerbout, H., Abtout, A. \& Gibert, D. (2008). Interpretation of aeromagnetic data in the Chlef region (Algeria) using the wavelet transform in the case 3-D. Third International scientific and practical Conference and exhibition EAGE ( The European Association of Geoscientists and Engineers) Saint Petersburg, Russia 2008.

Chiarabba, C., Amato, A. \& Meghraoui, M. (1997). Tomographic images of the El Asnam fault zone and the evolution of a seismogenic thrust-related fold. Journal of Geophysical Research., 102(B11), 24,485-24,498, doi:10.1029/97JB01778

Derder, M.E.M., Henry, B., Djellit, H., Dorbath, C., Ymel, H., Gharbi, S., Guemache, M. \& Abtout, A. (2009). Bloc rotation tectonics in northern Algeria revealed by paleomagnetic investigations in the "Mitidja" basin (Algiers area, Algeria), International Earthquake Symposium Kocaeli 2009, Turkey, 17-19 August 2009.

Derder, M.E.M., Henry, B., Amenna M., Bayou B., Maouche S., Besse J., Ayache M., (2011). Bloc rotation tectonics recorded in the Miocene magmatic rocks of "Beni Haoua" area (northern Algeria): preliminary paleomagnetic results. European Geosciences Union, General Assembly 2010, Vienna, Austria, 03 - 08 April 2011.

Demarest, H. H. (1983). Error analysis for the determination of tectonic rotation from paleomagnetic data. Journal of Geophysical Research, 88, 4321-4328.

Dewey, J.W. (1991). The 1954 and 1980 Algerian earthquake implications for the characteristic displacement model of fault behaviour. Bulletin of Seismological Society of America, 81, 446-467.

Ellwood, B. B. (1980). Induced and remanent properties of marine sediments as indicators in depositional processes. Marine Geology, 38: 233-244. 
Fisher, R. A. (1953). Dispersion on a sphere. Proceedings of the Royal Society of London, 217, 295-305.

Gradstein, F.M., Cooper, R.A., Sadler, P.M., Hinnov, L.A., Smith, A.G., Ogg, J.G., Villeneuve, M., McArthur, J.M., Howarth, R.J., Agterberg, F.P., Robb, L.J., Knoll, A.H., Plumb, K.A., Shields, G.A., Strauss, H., Veizer, J., Bleeker, W., Shergold, J.H., Melchin, M.J., House, M.R., Davydov, V., Wardlaw, B.R., Luterbacher, H.P., Ali, J.R., Brinkhuis, H., Hooker, J.J., Monechi, S., Powell, J., Röhl, U., Sanfilippo, A., Schmitz, B., Lourens, L., Hilgen, F., Shackleton, N.J., Laskar, J., Wilson, D., Gibbard, P. \& Van Kolfschoten, T. (2004). A Geologic Time Scale 2004. Cambridge University Press, 589 p.

Graham, R. H. (1978). Quantitative deformation studies in the Permian rocks of the AlpesMaritimes. Mémoire du Bureau de Recherche Géologique et Minière, 91, 219-238.

Henry, B., Merabet, N., Derder, M.E.M. \& Bayou, B. (2004a). Chemical remagnetizations in the Illizi basin (Saharan craton, Algeria) and their acquisition process. Geophysical Journal International, 156, 200-212.

Henry, B., Rouvier, H. \& Le Goff, M. (2004b). Using syntectonic remagnetizations for fold geometry and vertical axis rotation: example of the Cévennes border (France). Geophysical Journal International, 157, 1061-1070.

Hext, G. (1963). The estimation of second-order tensors, with related tests and designs. Biometrika 50, 353.

Idres, M., Ydri, A. \& Lefort, J.P. (1996). Proposition d'un schéma structural du bassin du Chelif (Algérie) à partir de données gravimétriques. Comptes Rendus de l'Académie des Sciences Paris, 322, IIa, 85-91.

Jelinek, V. (1978). Statistical processing of magnetic susceptibility measured in groups of specimens. Studia Geophysica et Geodaetica, 22, 50-62.

Jelinek, V. (1981). Characterization of the magnetic fabric of rocks. Tectonophysics 79, 63-67.

Kirschvink, J.L. (1980). The least-squares line and plane and the analysis of palaeomagnetic data. Geophysical Journal of the Royal Astronomical Society, 62, 699-718.

Mauffret, A., El Robrini, M. \& Gennesseaux, M. (1987). Indice de la compression récente en mer Méditerranée: un bassin losangique sur la marge algérienne. Bulletin de la Société Géologique de France (8), III, 6, 1195-1206.

McElhinny, M.W. (1964). Statistical significance of the fold test in paleomagnetism. Geophysical Journal of the Royal Astronomical Society 8, 338-340.

McFadden P.L. \& McElhinny M.W. (1990). Classification of the reversal test in palaeomagnetism. Geophysical Journal International, 103, 725-729.

McKenzie, D.P. (1972). Active tectonics of the Mediterranean region. Geophysical Journal of the Royal Astronomical Society, 30, 109-185.

Meghraoui, M. (1982). Etude néotectonique de la région nord-est d'El-Asnam: relation avec le séisme du 10 octobre 1980. 3th cycle thesis, Paris7 Univ., pp 210.

Meghraoui, M., Cisternas, A. \& Philip, H. (1986). Seismotectonics of the lower Chelif basin : structural background of the El-Asnam (Algeria) earthkaque , Tectonics, 5, 6, 809836.

Meghraoui, M. (1988). Géologie des zones sismiques du nord de l'Algérie: Paléosismologie, tectonique active et synthèse sismotectonique. Doct. Sci. Thesis, Univ. Paris XI, $356 \mathrm{pp}$. 
Meghraoui, M., Morel J.L., Andrieux J. \& M. Dahmani., 1996.Tectonique plio-quaternaire de la chaîne tello-rifaine et de la mer d'Alboran. Une zone complexe de convergence continent-continent. Bulletin de la Société Géologique de France, 167, 1, 141-157.

Meghraoui, M., Maouche, S., Chemaa, B., Cakir, Z., Aoudia, A., Harbi, A., Alasset, P.J., Ayadi, A., Bouhadad, Y. \& Benhamouda, F. (2004). Coastal uplift and thrust faulting associated with the $\mathrm{Mw}=6.8$ Zemmouri (Algeria) earthquake of 21 May, 2003. Geophysical Research Letters, 31, L19605, doi:10.1029/2004GL020466.

Morel, J.L. \& Meghraoui, M. (1996). Goringe-Alboran-Tell tectonic zone; a transpression system along the Africa-Eurasia plate boundary. Geology, 1996, 24, 8, 755-758.

Neurdin-Trescartes J. (1992). Le remplissage sédimentaire du bassin néogène du Chelif, modèle de référence de bassins intramontagneux. Doct. Sci. Thesis, Univ. de Pau et des Pays de l'Adour, France, 605 pp.

Nocquet, J. M. \& Calais, E. (2004). Geodetic measurements of crustal deformation in the Western Mediterranean and Europe. Pure and Applied Geophysics, 161, 661-681.

Rees, A.I. (1965). The use of anisotropy of magnetic susceptibility in the estimation of sedimentary fabric. Sedimentology, 4, 257271.

Rees, A.I. \& Woodall, W.A. (1975). The magnetic fabric of some laboratory-deposited sediments. Earth and Planetary Science Letters, 25, 121130

Rees, A.I., Von Rad, U. \& Shepard, F.P. (1968). Magnetic fabric of sediments from the La Jolla submarine canyon and fan, California. Marine Geology, 6, 145178.

Ron, H., Freund, R., Garfunkel, Z. \& Nur, A. (1984). Block rotation by strike-slip faulting: structural and paleomagnetic evidence. Journal of Geophysical Research, 89, 62566270 .

Ouyed, M., Meghraoui, M., Cisternas, A., Deschamp, A., Dorel, J., Frechet, F., Gaulon, R., Hatzfeld, D. \& Philip, H. (1981). Nature, 292, 5818, 26-31.

Perrodon, A. (1957). Etude géologique des bassins néogènes sublittoraux de l'Algérie du Nord occidental. Publications du service de la carte géologique de l'Algérie, 12, 343

Philip, H. \& Meghraoui, M. (1983). Structural analysis and interpretation of the surface deformations of the El-Asnam earthquake of October 10, 1980. Tectonics, 2, 1, 17-49.

Serpelloni, E., Vannucci, G., Pondrelli, S., Argnani, A., Casula, G., Anzidei, M., Baldi, P. \& Gasperini, P. (2007). Kinematics of theWestern Africa-Eurasia plate boundary from focal mechanisms and GPS data. Geophysical Journal International 169, 1180-1200

Thomas, G. (1985). Géodynamique d'un bassin intramontagneux: le bassin du bas Chéliff occidental (Algérie) durant le Mio-Plio-Quaternaire. Doct. Sci. Thesis, Univ. de Pau, France.

Weiler, P. D. (2007). Magnetic anisotropy, sedimentary rocks and strain alteration. In Gubbins D. and Herrero-Bervera E. (Eds), Encyclopedia of Geomagnetism and Paleomagnetism, Springer, 475-477.

Zijderveld, J.D.A. (1967). AC demagnetization of rocks: analysis of results. In: Collinson, D.W., Creer, K.M., Runcorn, S.K. (Eds.), Method in Paleomagnetism. Elsevier, Amsterdam, 254-286. 


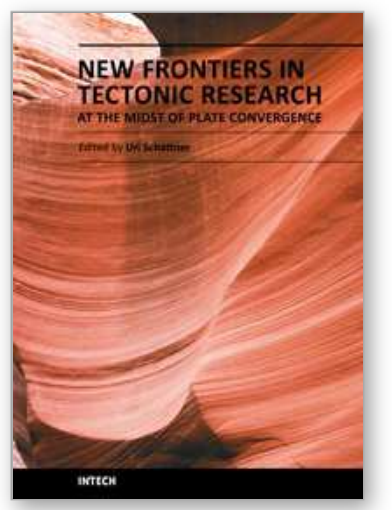

\section{New Frontiers in Tectonic Research - At the Midst of Plate Convergence}

Edited by Dr. Uri Schattner

ISBN 978-953-307-594-5

Hard cover, 352 pages

Publisher InTech

Published online 09, August, 2011

Published in print edition August, 2011

Ocean closure involves a variety of converging tectonic processes that reshape shrinking basins, their adjacent margins and the entire earth underneath. Following continental breakup, margin formation and sediment accumulation, tectonics normally relaxes and the margins become passive for millions of years. However, when final convergence is at the gate, the passive days of any ocean and its margins are over or soon will be. The fate of the Mediterranean and Persian Gulf is seemingly known beforehand, as they are nestled in the midst of Africa-Arabia plate convergence with Eurasia. Over millions of years through the Cenozoic era they progressively shriveled, leaving only a glimpse of the Tethys Ocean. Eventually, the basins will adhere to the Alpine-Himalaya orogen and dissipate. This book focuses on a unique stage in the ocean closure process, when significant convergence already induced major deformations, yet the inter-plate basins and margins still record the geological history.

\section{How to reference}

In order to correctly reference this scholarly work, feel free to copy and paste the following:

Derder M.E.M., Henry B., Amenna M., Bayou B., Maouche S., Besse J., Abtout A., Boukerbout H., Bessedik M., Bourouis S. and Ayache M. (2011). Tectonic Evolution of the Active "Chelif" Basin (Northern Algeria) from Paleomagnetic and Magnetic Fabric Investigations, New Frontiers in Tectonic Research - At the Midst of Plate Convergence, Dr. Uri Schattner (Ed.), ISBN: 978-953-307-594-5, InTech, Available from: http://www.intechopen.com/books/new-frontiers-in-tectonic-research-at-the-midst-of-plateconvergence/tectonic-evolution-of-the-active-chelif-basin-northern-algeria-from-paleomagnetic-and-magneticfabri

\section{INTECH}

open science | open minds

\section{InTech Europe}

University Campus STeP Ri

Slavka Krautzeka 83/A

51000 Rijeka, Croatia

Phone: +385 (51) 770447

Fax: +385 (51) 686166

www.intechopen.com

\section{InTech China}

Unit 405, Office Block, Hotel Equatorial Shanghai

No.65, Yan An Road (West), Shanghai, 200040, China

中国上海市延安西路65号上海国际贵都大饭店办公楼405单元

Phone: +86-21-62489820

Fax: $+86-21-62489821$ 
(C) 2011 The Author(s). Licensee IntechOpen. This chapter is distributed under the terms of the Creative Commons Attribution-NonCommercialShareAlike-3.0 License, which permits use, distribution and reproduction for non-commercial purposes, provided the original is properly cited and derivative works building on this content are distributed under the same license. 